\title{
EVALUASI KEBIJAKAN \\ PEMBANGUNAN INDUSTRI DI JAWA TIMUR \\ YANG BERWAWASAN SUMBER DAYA MANUSIA DALAM SUSTAINABILITY DEVELOPMENT
}

\author{
Agus Prianto, M. Sulhan \\ Universitas Yudharta Pasuruan
}

Article Histori:

Submited: 22/11/2022

Editing: 29/4/2020

Publish: 30/4/2020

\begin{abstract}
Di era industrialisasi dijawatimur memiliki masalah terutama SDM, budaya masyarakat, sistem sosial, yang bermuara pada kesejahteraan sosial. Kehadiran pemerintah pada Sektor industri sebagai penyedia lapangan kerja dengan peraturan tentang perkembangan indutrialization sejak 2018 pertumbuhan industrialisasi jawatimur mengalami kenaikan $14,48 \%$ yang hanya pada sektor Industri yang tumbuh pada sektor indutri manufaktur makanan 12,35\%, industri logam 17,97\%, indutri furnitur 21,50\% dan industri rekaman dan percetakan 27,25\%. Melihat pertumbuhan dan tidak sebanding dengan IPM jawatimur yang berkaitan dengan tenaga kerja maka perlu dikompromikan tentang penguatan terhadap sektor informal di Jawa Timur sekaligus adanya perlindungan pekerja di sektor informal baik dalam manajemen dan regulasinya.
\end{abstract}

Keyword: kesejahteraan, industrialisasi dan sektor informal.

\section{PENDAHULUAN}

Kebijakan pembangunan kearah Indutrialisasi memiliki dampak atas keterpurukan bagi masyarakat. Hal ini disebabkan bahwa mainset industrialisasi menjadi paradigma pembangunan diera global bagi negara Indonesia yang memiliki konsekuensi logis atas keberadaan negara berkembang (NSB) untuk ikut merubah kebijakan pembangunan kearah Industrialisasi dengan adanya 5 tahapan; transformasi sosial dari Tradisional, Pra-take off, take off, maturity and Hight Consumtion (WW. Rowstow)
Outline pembangunan di Indonesia terlihat pada dokumen atas Rencana Pembangunan Jangka Panjang (RPJP) Tahun 2005 dan 2025 yang menciptakan Indonesia yang aman dan damai, adil dan demokratis serta tingkat kesejahteraan meningkat dengan mengembangkan Iptek sekaligus penguasaan daya saing perekonomian yang berlandaskan keunggulan SDA dan SDM berkualitas serta kemampuan yang terus meningkat untuk mewujudkan masyarakat Indonesia yang mandiri, maju, adil dan makmur melalui 
percepatan pembangunan diberbagai bidang.

Hal ini dilakukan dengan menekankan terbangunnya struktur perekonomian yang kokoh berlandaskan keunggulan kompetitif diberbagai wilayah didukung SDM berkualitas dan berdaya saing sehingga mengembangkan teknologi, dalam konteks teknologi sebagai ideologi merupakan adoption policy kearah Indutrialisasi sebagimana pemikiran Raul Prebisch Subtitution Import (Adewale, 2012) yang memvisualisasi atas negara Amerika Latin yang telah tersadarkan atas kondisi keterpurukan untuk mampu melakukan Industrialisasi.

Indutrialisasi tidak selamanya menjadi tesis atas masalah perburuhan dan kesejahteraan masyarakat. Pada tentunya dunia Indutrialisasi menuntut untuk selalu melakukan inovasi teknologi guna memenuhi prinsip efisiensi dalam dunia usaha karena fakta pembangunan indutrialisasi dan teknologi saling ketergantungan dan memiliki hubungan (Rosyadi, 2018) sehingga tidak mampu memberikan kontribusi atas penyediaan lapangan pekerjaan karena sumberdaya manusia yang kurang bisa mengimbangi kemanjuan teknologi dan juga pengurangan jumlah pekerja sedangkan dalam konteks reformasi administrasi mendorong adanya change of struktural (Caiden, 1991) dengan memberlakukan sistem otonomi daerah yang memberikan kewenangan kepada pemerintah daerah dalam urusan wajib dan urusan pilihan, hal ini termasuk urusan industrialisasi yang mengalami dinamika terhadap kewenangan yaitu pemerintah daerah yang diamanatkan dalam UU 23 tahun 2014).

Sebagaimana dalam laporan World Bank (2009) yang mempelajari kasus industrialisasi memiliki masalah atas kemampuan penyerapan tenaga kerja disektor industri yang selalu melakukan inovasi dan berfikir efisiensi, belum lagi ditengah globalisasi yang berpeluang tenaga kerja asing untuk masuk ke indonesia dan menjadi pesaing dengan warga Indonesia yang diberlakukannya Permenaker 229 Tahun 2019 tentang tentang jebatan tertentu yang dapat diduduki oleh tenaga kerja asing.

Data penyerapan tenaga kerja diindonesia pada era Indutrialisasi masih bermasalah, sebagaimana laporan Badan Statistik Tahun 2016 yang melihat angka penggauran pada usia Produktif (15 Tahun) di Jawa Timur Mencapai 384.742 tinggi kedua setelah Propoinsi Jawa Barat sampai mencapai angka 616.331

Sebagimana data statistik BPS Tahun 2016 juga melihatkan atas tenaga kerja yang diserap berdasarkan sektoral, sebagaimana sumber Laporan Sensus Ekonomi tahun 2016 oleh BPS Sektor yang mampu menyerap tenaga kerja berada diklaster 1 adalah pada sektor Pertanian, Kehutanan, Perburuan, Perikanan, Agricultur, Foresty dan fisheries sebanyak 14.060.893, kluster 2 pada sektor perdagangan besar dan eceran, rumah makan, Hotel retail trade dan restourant sebanyak 15.065 .772 sedangkan sektor industri menjadi kluter ke 4 setelah sektor jasa kemasyarakatan dengan sebanyak 9.395.166 sedangkan sektor industri sebanyak 6.623.456. dan sisanya dibagi dengan 6 kluter lainnya.

Pembangunan Indutrialisasi terlihat pada tingkat serapan apakah ada diskriminasi terhadap gender atas berlakunya system demokrasidan berlakunnya HAM di masaindutrialisasi terhadap pasar tenaga kerja dan perubahan nkeluarga, perempuan bekerja dan keguncangan budaya tradisional (Rahardjo, 2013).

\section{KAJIAN LITERATUR}


James E. Anderson (1979:3) mengartikan "public policies are those policies developed by onvoirepmental bodies and officials" (kebijakan negara adalah kebijakankebijakan yang dikembangkan oleh badanbadan dan pejabat-pejabat Pemerintah). Dalam proses pembuatan kebijakan publik (policy maker) tidak hampa nilai value free, namun harus dengan sarat nilai value laden dengan dibarengi kepekaan terhadap kepentingan publik untuk itu kebijakan pembangunan indutrialisasi merupakan aktivitas yang dilakukan oleh pemerintah, masyarakat, dan pihak swasta berlangsung secara terus-menerus dan berkesinambungan dengan tujuan untuk meningkatkan kesejahteraan rakyat, baik pada aspek materiil maupun spiritual (Afandi \& Warjio, 2015).

Nilai dalam kebijakan pemerintah dipengaruhi oleh faktor tertentu yang berkaitan oleh Nigro (1951) menjelaskan ada beberapa faktor yang mempengaruhi pembuatan kebijakan, diantaranya:

1. Pengaruh tekanan dari luar

2. Pengaruh kebiasaan lama (konservatif)

3. Pengaruh sifat pribadi

4. Pengaruh dari kelompok luar, dan

5. Pengaruh kondisi masa lalu.

Dalam perumusan kebijakan publik merupakan otoritas Pemerintahan sebagai kinerja kebijakan (Wahyudi, 2016). Problem yang dihadapi dalam pembangunan menjadikan penyebab kurang maksimalnya sektor industri dalam menyerap tenaga kerja di sebabkan industrialisasi selalu berprinsip pada efisiensi dan efektifitas kinerja dengan berinovasi pada teknologi (Rosyadi,2018) sedangkan SDM pada Negara sedang berkembang memiliki keterbatasan sehingga kurang mampu mengikuti atas perkembangan teknologi. Sehingga kegagalan sektor indutri dalam menyediakan kebutuhan sektor publik dalam lapangan pekerjaan yang kaitannya dengan Kesejahteraan Masyarakat. Perlu menyelaraskan strategi tentang akuisisi teknologi dengan sumber daya pra-masuk dan pasca-masuk dengan kemampuan (Chen \& Chen, 2016).

Problem pembangunan pada indutrialisasi dijawa timur bagian dari RIPIN 2015-2035 dan KIN yang tertuang dalam Rencana Induk Pembangunan Indutri Nasional Peraturan Pemerintah Nomor 14 Tahun 2015 sebagimana Pasal 4 yang mejelaskan tentang kebijakan Industrial dan menjadi rencana jangka Menengah Pembangunan, hal ini memiliki keterkaitan pembangunan jangka menengah daerah pada industrial sehingga mampu mendukung pembangunan Indutri di Jawa timur dengan Misi Utama Pemerintah Jawa timur adalah penguatan Industri dan percepatan Investasi.

Dampak globalisasi yang mendorong pemerintah untuk menciptakan kesejahteraan dengan upaya mekanisme tenaga kerja menjadi bursa pasar tenaga kerja mewajibkan atas kekuatan Negara dalam mewujudkan kesejahteraan dalam masa transisi Industri, sebab pergeseran sejalan dengan ketidak relavansiannya dominasi peran Negara (Keynesian) pada system ekonomi pasar global (Cenry, 1999 dalam Martanto, 2002, p.77) sehingga perlu adanya kajian masyarakat industry sebagai sarana kebijakan untuk menciptakan kesejahteraan terlebih pada masyarakat plural dan memiliki kompleksitas problem dan kepentingannya yang berwawasan sustainability development memiliki empat dimensi, yaitu : 1). Ekologis, 2). Sosial ekonomi budaya, 3). Sosial politik, dan 4) Hukum Kelembagaan (Dahuri,2004 : 154)

\section{METODE PENELITIAN}

Penelitian berobjek pada evaluasi pembangunan Industri di jawatimur tentang penyediaan lapangan tenaga kerja sebagai wujud pembangunan berkelanjutan yang menggunakan pendekatan kualitatif 
deskriptif. Penelitian ini bertujuan memberi gambaran atau paparan terhadap peristiwa yang diteliti tentang implikasi terhadap social ketenaga kerjaan sebagai tanggung jawab kesejahteraan.

Pengumpulan data dalam penelitian ini dilakukan dengan observasi atau pengamatan terhadap objek Denszin dan Lincolin (2009.). Disamping itu, pengumpulan data juga melalui studi kepustakaan (library research) yang juga disebut sebagai teknik dokumentasi yang ditunjukkan untuk menggambarkan fenomena-fenomena apa adanya. Dalam penelitian ini, deskriptif yang dimaksud adalah analisis media dengan deskriptif kualitatif.

\section{HASIL DAN PEMBAHASAN}

Industrialisasi dinegara berkembang sangat dipengaruhi oleh situasi Negara tersebut, sehingga diperlukan sebuah tata kelola yang baik good Management. Easton (dalam Islamy, 2004:19), memberikan arti kebijakan negara sebagai "the authoritative allocation of values for the whole society" (pengalokasian nilai-nilai secara paksa kepada seluruh anggota masyarakat). Berdasarkan definisi tersebut menegaskan hanya pemerintahlah yang secara sah dapat berbuat sesuatu atau tidak melakukan Sejalan dengan pernyataan tersebut, Kebijakan pembangunan industri yang dipengaruhi kuat atas faktor informal (budaya, kepribadian, etoskerja), dan teknologi dalam industrialisasi mendorong dampak atas problem pembangunan Industri turut serta terhadap problem sebagaimana upaya ditengah pembangunan Industri jawa timur harus mengutamakan atas hak kesejahteraan maka menjadi kinerja pemerintah untuk menciptakan pasar lapangan pekerjaan, sebagai upaya atas tantangan dimasa globalisasi, menuntut peran Negara untuk membuat inovasi untuk mengurangi ketergantungan pada sumber daya alam dan lebih tergantung pada Sumber daya manusia sebagai konsekuensi adanya tekanan untuk andil dalam persaingan global dengan membuka luas lapangan pekerjaan dan menciptakan pembangunan industri yang efisien (Goh, 2005).

Globalisasi di jawatimur memiliki konsekuansi terhadap penyediaan pelayanan sector tenaga kerjaan. Ditahun 2010 s.d 2015 dengan adanya peningkatan penduduk yang relative meningkat dijawa timur dimana tingginya pertumbuhan penduduk memiliki dampak atas luasnya dan ketercukupan lapangan pekerjaan formal pada indutrialisasi.

Pertumbuhan penduduk tersebut memberikan dampak atas ketersediaan lapangan pekerjaan yang membangun atas kebijakan kesejahteraan masyarakat. Dengan tingkat kesejahteraan yang baik, maka mampu untuk menjadi kompetitor di era global, persoalannya adalah jumlah penduduk yang tinggi dan tingkat sumber daya manusia rendah maka menjadi masalah penghambat tersendiri.

Kebijakan indutrialisasi memang menjadi Road Mapp Pembangunan Indonesia dan tertuang dalam RPJP dan RPJM Jawa timur harus selaras dengan kebijakn di tiap kab/kota. Oleh sebab itu nampak atas tingginya industrialisasi terbanyak masih didominasi oleh kempok industry makanan, yaitu; masih didominasi oleh kempok industri makanan, yaitu sebanyak 1.801 perusahaan $(27,82 \%)$, industri tekstil sebanyak 537 perusahaan $(8,30 \%)$, dan industri pengolahan tembakau berjumlah 446 perusahaan $(6,89 \%)$, industri karet, barang dari karet dan plastik sebanyak 431 perusahaan $(6,66 \%)$, industri furnitur sebanyak 399 perusahaan $(6,16 \%)$, dan industri kayu, barang dari kayu dan gabus (tidak termasuk furnitur) dan barang 
anyaman dari bambu, rotan dan sejenisnya sebanyak 353 perusahaan $(5,45 \%)$.

Sedangkan kelompok industri jumlahnya paling sedikit adalah industri produk dari batu bara dan pengilangan minyak bumi sebanyak 23 perusahaan $(0,36$ $\%)$, jasa reparasi dan pemasangan mesin dan peralatan sebanyak 29 perusahaan $(0,45 \%)$, industri komputer, barang elektronik dan optik sebanyak 36 perusahaan $(0,56 \%)$, industri farmasi, produk obat kimia dan obat tradisional sebanyak 59 perusahaan $(0,91 \%)$, dan industri kendaraan bermotor, trailer dan semi trailer serta industri alat angkutan lainnya yaitu masing-masing sebanyak 65 perusahaan $(1,00 \%)$.

Tabel 1.

Jumlah dan laju Pertumbuhan Penduduk Propinsi Jawa Timur 2010-2015

\begin{tabular}{|c|c|c|c|c|c|c|}
\hline \multirow{2}{*}{\multicolumn{2}{|c|}{ Kabupaten/Kota }} & \multicolumn{3}{|c|}{ sumlah Penduduk (ribu) } & \multicolumn{2}{|c|}{$\begin{array}{l}\text { Laju Pertumbuhan Penduduk per } \\
\text { Tahun (\%) }\end{array}$} \\
\hline & & 2010 & 2014 & 2015 & $2010-2015$ & $2014-2015$ \\
\hline \multicolumn{7}{|c|}{ Kabupaten } \\
\hline 1. & Pacitan & 541799 & 549481 & 550986 & 0,34 & 0,27 \\
\hline 2. & Ponorogo & 856682 & 865809 & 867393 & 0,25 & 0,18 \\
\hline & Trenggalek & 675584 & 686781 & 689200 & 0,40 & 0,35 \\
\hline 4. & Tulungagung & 992317 & 1015974 & 1021190 & 0,58 & 0,51 \\
\hline 5. & Blitar & 1118919 & 1140793 & 1145396 & 0,47 & 0,40 \\
\hline 6. & Kediri & 1503095 & 1538929 & 1546883 & 0,58 & 0,52 \\
\hline 7. & Malane & 2451997 & 2527087 & 2544315 & 0,74 & 0,68 \\
\hline $\mathbf{s}$. & Lumajang & 1008486 & 1026378 & 1030193 & 0,43 & 0,37 \\
\hline & Jember & 2337909 & 2394608 & 2407115 & 0,59 & 0,52 \\
\hline 10. & Banyuwangi & 1559088 & 1588082 & 1594083 & 0,44 & 0,38 \\
\hline 11. & Bondowoso & 738383 & 756989 & 761205 & 0,61 & 0,56 \\
\hline 12. & situbondo & 649092 & 666013 & 669713 & 0,63 & 0,56 \\
\hline 13. & Probolingeo & 1099011 & 1132690 & 1140480 & 0,74 & 0,69 \\
\hline 14. & Pasuruan & 1516492 & 1569507 & 1581787 & 0,85 & 0,78 \\
\hline 15. & sidoarjo & 1949595 & 2083924 & 2117279 & 1,66 & 1,60 \\
\hline 16. & Mojokerto & 1028605 & 1070486 & 1080389 & 0,99 & 0,93 \\
\hline 17. & Jombang & 1205114 & 1234501 & 1240985 & 0,59 & 0,53 \\
\hline 18. & Nganjuk & 1019018 & 1037723 & 1041716 & 0,44 & 0,38 \\
\hline 19. & Madiun & 663476 & 673988 & 676087 & 0,38 & 0,31 \\
\hline 20. & Magetan & 621274 & 626614 & 627413 & 0,20 & 0,13 \\
\hline 21. & Ngawi & 818989 & 827829 & 828783 & 0,24 & 0,12 \\
\hline 22. & Bojonegoro & 1212301 & 1232386 & 1236607 & 0,40 & 0,34 \\
\hline 23. & Tuban & 1120910 & 1147097 & 1152915 & 0,56 & 0,51 \\
\hline 24. & Lamongan & 1180699 & 1187084 & 1187795 & 0,12 & 0,06 \\
\hline 25. & Gresik & 1180974 & 1241613 & 1256313 & 1,24 & 1,18 \\
\hline 26. & Bangkatan & 909398 & 945821 & 954305 & 0,97 & 0,90 \\
\hline 27. & Sampang & 880696 & 925911 & 936801 & 1,24 & 1,18 \\
\hline
\end{tabular}

Sumber ; Laporan Sensus Ekonomi Tahun 2016 oleh BPS

Jumlah tenaga kerja yang terserap pada perusahaan industri manufaktur besar dan sedang di Jawa Timur selama tahun 2014 sebanyak 1.076.217 orang dari jumlah penduduk pada tahun tesebut sebanyak 38.610.000 juta jiwa dengan asumsi $69.2 \%$ (tabel 1) pada usia produktif (pekerja) sehingga dari angka tersebut angka indek partisipasi kerja di jatim relatif rendah sebagaimana angkatan kerja di tahun 2015 2017 mengalami kenaikan (tabel 2).

Tabel 2. Indek Angka Partisipasi Tenaga Kerja Di Jawa timur

\begin{tabular}{|c|c|c|c|c|c|c|c|}
\hline \multirow{2}{*}{ Jenis Kegiatan Utama } & \multirow{2}{*}{ Satuan } & \multicolumn{2}{|c|}{2015} & \multicolumn{2}{|c|}{2016} & \multicolumn{2}{|c|}{2017} \\
\hline & & Februari & Agustus & Februari & Agustus & Februari & Agustus \\
\hline (1) & (2) & (3) & (4) & (s) & (6) & (7) & (8) \\
\hline 1. Angkatan Kerja (AK) & juta & 20,69 & 20,27 & 20,50 & 19,95 & 20,89 & 20,94 \\
\hline Bekerja & juta & 19,80 & 19,37 & 19,65 & 19,11 & 20,03 & 20,10 \\
\hline Penganggur & juta & 0,89 & 0,91 & 0,85 & 0,84 & 0,86 & 0,84 \\
\hline $\begin{array}{l}\text { 2. Tingkat Partisipasi Angkatan } \\
\text { Kerja }\end{array}$ & $\%$ & 69,58 & 67.84 & 68,27 & 66,14 & 68,93 & 68,78 \\
\hline $\begin{array}{l}\text { 3. Tingkat Pengangguran Ter- } \\
\text { buka (TPT) }\end{array}$ & $\%$ & 4,31 & 4,47 & 4,14 & 4,21 & 4,10 & 4,00 \\
\hline 4. Pekerja Tidak Penuh & $\%$ & 6,41 & 6,24 & 6,28 & 5,60 & 6,26 & 5,73 \\
\hline Setengah Penganggur & juta & 1,63 & 1,63 & 1,61 & 1,34 & 1,23 & 1,23 \\
\hline Paruh Waktu & juta & 4,78 & 4,62 & 4,66 & 4,26 & 5,03 & 4,47 \\
\hline
\end{tabular}


Sumber : Laporan Sensus Ekonomi Tahun 2016 oleh BPS

Yang artinya, bahwa banyak lulusan akan berdampak pada kebutuhan lapangan pekerjaan. Sebagaimana rencana Indutrialisasi di jawa timur, memiliki dampak atas ketersediaan lapangan kerja yang daya serap meliputi; Indutri Tektil (537 Orang), Indutri Tembakau (446 orang), Indutri Karet (432 orang), Industri Furnitur (391 orang) dan Indutri kayu (353 orang) dan beberap industri tersebut indentik dengan teknologi didalam produksi maka secara otomatis didalam industrialisasi masih belum bisa menyerap tenaga kerja oleh sebab itu angka partisipasi kerja masih rendah yang masih stagnan atau berkisar antara 66 - $69 \%$. Sehingga separuh masyarakat berada pada pekerja tidak penuh (pengangguran terselubung.)

Rendahnya permasalahan rendah angka partisipasi kerja dan pengangguran terselubung dijawa timur, sebab kesenjangan antar daerah yang terlihat pada tingkat pendidikan dan berdampak pada aspek kehidupan lainnya. Sehingga dalam membangun kesejahteraan masyarakat jawa timur dari sektor indutri mengalami kendala dan menimbulkan permasalahan dengan munculnya disparitas dam pengangguran. Untuk industrialisasi yang menghendaki teknologi dan adanya revolusi industri 4.0 yang memiliki konsekuensi terkait teknologi yang tidak di ikuti akan sumber daya manusia di jawatimur sehingga memiliki dampak atas rendahnya kesejateraan masyarakat.

Guna mengemban tanggung jawab, pemerintah perlu adanya kerjasama dengan pihak swasta dan masyarakat didalam menyediakan lapangan pekerjaan sebagimana tujuan mensejahterakan kehidupan masyarakat welfarestate. Tanggung jawab yang di emban pemerintah juga dihadapi problem atas keterbatasan sehingga dalam kebijakan ketenagakerjaan masih belum bisa terpenuhi, sejalan dengan pertumbuhan jumlah penduduk, perbedaan taraf pendidikan, aksesbilitas informasi, kwalitas pendidikan antar daerah berbeda, budaya yang belum mendukung dan masyarakat transisi dari sektor pertanian menuju indutri menjadi permasalahan yang harus diselesaikan dengan cara bekerjasama dengan pihak lain. Pendekatan kerjasama membahas dan menempatkan sektor swasta (informal) sebagai patnership untuk membuka lapangan pekerjaan dibidang Informal hal ini sejalan dengan upaya paradigma governance yang memberikan ruang publik public sphare.

Meksipun dalam regulasi belum ada yang mengatur tentang kedudukan informal dalam kerjasma sehingga pemerintah harus segera membuat kebijakan disektor informal. Didalam prinsip kerjasama masih menempatkan pemerintah sebagai pemangku kepentingan sekaligus provider didalam berbagai jaminan sosial pada sektor informal.

Prinsip kerjasama selalu mengedepankan kontrak antar mitra, sebagaimana setiap mitra memiliki kepentingan baik bersifat profit atau non profit. Kerjasama kolaboratif juga bersifat kemitraan, jejaring yang menguhubungkan secara independensi untuk memenuhi kebutuhan publik, meskipun sektor swasta berfikir atas keuntungan dari memahami bagaimana pemerintah didalam melakukan kerjasama, pilihan dan trade off yang dihadapi, sehingga peran pemerintah daerah di jawatimur secara fleksibel dapat menghadapi kepentingan kerjasama antar mitra. Banyaknya pengangguran merupakan wujud atas kegagalan transfrormasi ketenagakerjaan yang hanya bisa menampung $60 \%$ tenaga kerja ditiap 
tahun, dan tentunya ditiap tahun ada kenaikan atas jumlah tenaga kerja $2 \%$ ditiap tahunnya. Maka sektor informal sangat penting untuk penopang, namun ada beberapa faktor untuk kesiapan atas dukungan didalam kerjasama didalam penyiapan ketenagakerjaan disektor informal; Kemudahan sistem perizinan disektor informal Standarisari kesejahteraan (upah) sektor informal serta adanya sistem perlindungan sosial tenaga kerja sektor informal.

Ketiga faktor tersebut, menempatkan sisi peranan pemerintah didalam kerjasama antar sektor sehingga mengurangi atas tumpang tindih peranan sektor publik yang menempatkan pemerintah menjadi penengah yang membuat kebijakan baik program ataupun regulasi, posisi pemerintah dalam kebijakan pengembangkan sektor informal sebagai jaringan bisa berbentuk Ad-Hoc Collaboration dan patnership. Sebagimana pengemangan sektor informal masih butuh untuk evaluasi karena sebagai jaminan sistem perlindungan sosial tenaga kerja informal, penguatan dalam mekanisme pengupahan, mengantisipasi ketimpangan bagi tenaga unskill.

Kemampuan perlindungan atas jaminan sektor informal dapat membantu pemerintah dalam sistem jaminan sosial tenaga kerja, sebagaimana data Sakernas, 20013 dan PT Jamsostek 2013. Sektor informal mampu menyerap tenag kerja hingga 67.5 juta jika sedangkan sektor formal hanya bisa menyerap tenag kerja $46.6 \%$ juta jiwa dengan kemampuan keikutsertaan jamsostek formal lebih tinggi $62,4 \%$ ketimbang informal sebesar $0,02 \%$. (Grafik. 3)

Gambar 1. Penyerapan lapangan Kerja dan Jamsostek

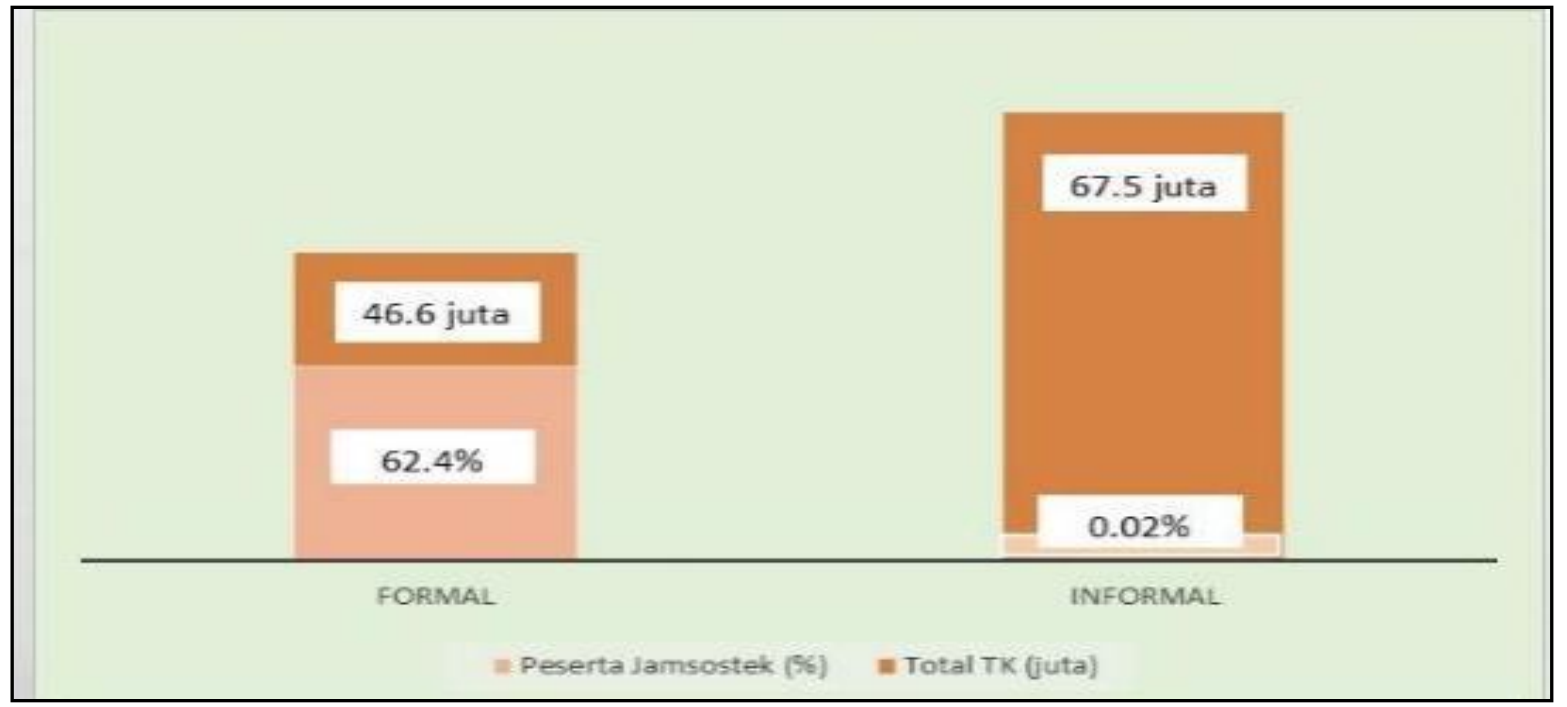

Sumber: Sakernas 2013 (Februari) dan PT. Jamsostek (2013)

Dari data tersebut, maka perlu Pemerintah Jawatimur membuat Regulasi Khusus terkait Jamsostek tenagaka kerja Sektor Informal, yang mengatur tentang mekanisme kepesertaan tenaga kerja Informal terhadap program Jamsostek baik sisi Iuran, Peranan Negara, Adopsi dalam SISN tenaga kerja Informal.
Kegagalan sektor formal ditengah era indutrialisasi maka Permerintah perlu mengevaluasi kembali sistem perizinan untuk lebih terjangkau dalam aspek biaya, kemudahan prosedur sehingga pelembagaan dalam mekanisme perizinan dapat mengetahui jumlah pasti sektor informal dan memudahkan didalam 
pengembangan dalam sisi permodalan. Dengan memiliki jumlah sektor informal yang resmi, akan mudah didalam collaboration lintas sektor untuk tranformasi ketenagakerjaan formal dan informal.

\section{PENUTUP}

Ketenegakerjaan menjadi masalah yang ralitif komplek di jawatimur, ketengakerjaan menjadi salah satu trend pembangunan kesejahteraan dijawatimur, maraknya indutrialisasi akan menjadi masalah tatkala dihadapi kesejangan sosial dan patologi. Sehingga diperukan sinergisitas atas kegegalan dalam transformasi ketenagakerjaan pada sektor Industrialisasi disisi lain.

Kegagalan sektor indutri dapat di topang oleh memkasimalkan sektor informal yang dapat menyerap tenaga kerja dan mampu bertahan dengan cirikhas teknologi yang masih bermuara pada ketersediaan lapangan pekerjaan. Dengan kerjasama pemerintah dengan pihak informal dan memberikan protektif dan stimulan dalam bentuk kerjasama, maka akan mampu membuat lapangan ketenagakerjaan berada pada posisi Ad Hoc Collaboration dan atau Patnerhip dengan memperkuat regulasi di sektor informal dan adanya standar upah dan jaminan sosial ketenagakerjaan pada sektor informal dab kemudahan atau prosedur, dan mekanisme perolehan pengambangan permodalan yang bekerja sama dengan perbank kan guna permodalan usaha sektor informal maka kesejahteraan masyaraiat jawa timur pada daerah indutri akan bisa di jawab dengan arif terhadap lingkungan

\section{DAFTAR PUSTAKA}

Adewale, A. R. (2012). Does Import Substitution Industrialisation Strategy Hurt Growth ?: New Evidence from Brazil and South Africa, 11, 288-314. https:// doi.org/10.1163/1569210812341235

Chen, J., \& Chen, Y. (2016). New industry creation in less developed countries - the case of the Taiwanese flat panel display industry. Innovation, 17(2), 250-265. https:// doi.org/10.1080/14479338.201 5.1036542

Dahuri, Rokhim, dkk (2004) Pengelolaan sumber daya alam pesisir dan lautan secara terpadu. Jakarta. Pradnya paramitha

Denzin \& Lincoln. 2009. Handbook of Qualitative Research. Yogyakarta : Pustaka Pelajar

Goh, A. L. S. (2005). International Journal of Public Sector Management Emerald Article: Promoting innovation in aid of industrial development: the Singaporean experience Promoting innovation in aid of industrial development: the Singaporean experience.

https:// doi.org/10.1108/095135505105 91524

Islamy, Irfan M, (2008). Prinsip-prinsip Perumusan Kebijaksanaan Negara Jakarta: PT. Bina Aksara.

Martanto, Ucu. (2002). Kebijakan Sosial dan Kesejahteraan. FISIPOL UGM

Rosyadi, Slamet (2018) Revolusi Industri 4.0 Peluang Dan Tantangan Bagi Alumni Universitas Terbuka, di download https://scholar.google.co.id/scholar

Wahyudi, A. (2016). Implementasi rencana strategis badan pemberdayaan masyarakat dan desa dalam upaya pengembangan Badan Usaha Milik Desa di Kabupaten Kotawaringin Barat. Jurnal Ilmiah Administrasi Publik , 2(2), 101-105. Retrieved from http://ejournalfia.ub.ac.id/index.php /jiap/article/view/566/851 